\title{
DETERMINATION OF TOTAL ANTIOXIDANTS AND CAROTENOIDS IN FORTIFIED WHITE BREAD WITH DIFFERENT LEVELS OF DRIED POTATO PEELS
}

\author{
By \\ Th. M. H.Gouda \\ Lecture of Nutrition and Food Science, \\ Home Economics Department, Faculty of \\ Specific Education, Fayoum University
}

Research Gournal Specific Fducation

Faculty of Specific Fducation

gMansoura University

ISSUE NO. 45, JANUARY. 2017

مجلة بحوث التزبية النوعية - جامعة المنصورة

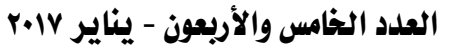


—Determination Of Total Antioxidants And Carotenoids In Fortified White Bread With Different Levels 


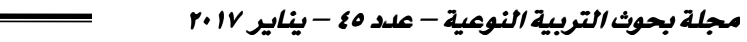

\title{
DETERMINATION OF TOTAL ANTIOXIDANTS AND
}

\section{CAROTENOIOS IN FORTIFIED WHITE BREAD WITH DIFFERENT LEVELS OF DRIED POTATO PEELS}

\author{
Th. M. H.Gouda*
}

\section{Abstract}

Antioxidants and carotenoids are considered good sources and necessary for human health. The aim of this work was to determinate of the total antioxidants and carotenoids in fortified bread with different levels of dried potato peels $(5 \%, 10 \%$ and $15 \%)$. It is used wheat flour $(72 \%$ extraction) and dried potato peels in oven at temperature (180 o $\mathrm{C}$ for 15 minutes) to raise nutritional value of antioxidants and carotenoids in bread. The bread was divided into two main groups, the first group (non- fortified) consisted of bread, and the second group consisted of fortified bread with potato peels and divided into three sub-groups they are as follows: fortified bread with $(5 \%, 10 \%$ and 15\%) respectively potato peels. The obtained results revealed that sensory evaluation of bread was acceptable sensory until level (15\%) dried potato peels compared to the control group and there were significant different with increasing potato peels, but the best result appeared in fortified bread with the (5\%),also there were significant differences (significant increasing) in the rats of vitamins and minerals with increasing potato peels compared to control group of bread . on the other hand the content of antioxidants and carotenoids in fortified bread were revealed that with increasing the level of dried potato peels increased of antioxidants and carotenoids (17.22, 35.13 and 55.86) respectively and carotenoids $(74.9,121.23$ and 151.58$)$ respectively as compared to control bread (0.00 and 27.4).It can be recommended that its necessary to utilization of potato peels in bakery products for important of nutritional values and healthy bread.

* Lecture of Nutrition and Food Science, Home Economics Department, Faculty of Specific Education, Fayoum University 
Key words: Antioxidants, Carotenoids, potato peels, wheat flour , sensory and chemical evaluation .

\section{INTRODUCTION:}

Carbohydrates are considered important and necessary nutrients for human health according to food agricultural organization [FAO, 1997]. Bread is one of the basic products for human diet. It is a source of energy and rich in carbohydrates, [Bowles and Demiate, 2006].A dietary supplement is providing human body with enough essential nutrients such as vitamins, minerals and fiber, especially people consume insufficient quantities. [Food and drug administration, 2014 and Crésio Alves and Renata Villas Boas Lima, 2009.]. And this is shown deficiency in micronutrients [Guallar et al., 2013].

Fruits and vegetables are considered of the foods with high content of potassium which helps maintain lean body mass and bone mineral density. [Dawson-Hughes et al., 2008].Vegetables and fruits peels are characterized as the best herbal extracts, it is rich in bioactive compounds and it has been biological properties [Parmar and Kar, 2009 \& Hamendra et al., 2010]. Among these vegetables are potatoes, it is one of the popular vegetables and important in the United States. [Lin and Yen, 2004 and Faostat, 2009]. Potatoes became basic foods in human nutrition, which it is considered natural source of phenolics and antioxidants, these compounds are found heavily in the peel, so potato peels is considered a natural source of strong antioxidants properties, high in the content of polyphenols and other phenolic compounds such as chlorogenic acid (50.31\%), glucaric acid. Gallic acid (41.67\%), protocatechuic $(7.81 \%)$ and caffeic acid (0.21\%).[Brown, et al $2005 \&$ Fischer and Bipp, 2005].The role of antioxidants are decrease the risk of coronary heart diseases [Venketeshwer, 2012 \& Lachman et al, 2008]. One medium potato with peel is contains two grams of fiber of the daily value, which it has health benefits in improving blood lipid levels, regulating blood glucose, and help weight loss, also potatoes are riches in vitamin $\mathrm{C}$, it is provide with $45 \%$ of vitamin $\mathrm{C}$ and this makes potatoes in the top 5 of vitamin $\mathrm{C}$ for Americans, Potato peels are provide the body with important minerals such as potassium $(620 \mathrm{mg}$ of potassium) more than high foods in the content of potassium such as 
bananas, oranges, mushrooms which it reduce the risk of hypertension, stroke and heart diseases Also it is contain of magnesium, phosphorous, iron, and zinc and vitamins for example $10 \%$ of vitamin B6, thiamin, riboflavin, folate, and no fat.The water soluble vitamins acts as an antioxidant, and help to prevent cellular damage and vitamin $\mathrm{C}$ assists with the absorption of iron and help support the body's immune system [Gropper et al., 2009 \& FDA, 2002 \& Cotton et al, 2004 \& \& Food and Nutrition Board, 2004 \& Cook et al, 2009 and Nowson et al, 2004].

More than 50\% of the nutrients found in the potato peels such as total dietary fiber, so Potato peels (PP) is considered a source of dietary fiber for human health [Stushnoff et al., 2007 \& Mabrouk and El Ahwany., 2008 \& Ballesteros et al., 2001]. [Nara et al., 2006] studied that physical and chemical properties of potato peels and reported that potato peels is containing a high rate of dietary fiber more than wheat bran. [Sello, 2011] Evaluated the content phenolic of potato and apple peels, the results showed that potato peel has high levels of copper (0.826), calcium (39.2), copper (0.68) and calcium (26.03) ppm. And the content of total phenols in potato peel was higher than apple peel (3.2 vr 2.5) respectively and the compounds of phenolic are distributed between the potato cortex and peel tissues, also $50 \%$ of the phenolic compounds are found in the potato peel a nearby tissues [Friedman, 1997 \& Hasegawa et al, 1966]. Compared between sesame cake, sugar beet pulp and potato peels, the results were showed that potato peels was superior in the content of Polyphenolic and antioxidant, these compounds have a role in human health [Mohdaly et al, 2010 \& AlWeshahy and Rao, 2012]. [Rasha and Nareman, 2013] compared between potato and eggplant peels and they reported that potato peels are better than eggplant peels in levels of chlorogenic acid. And the content of total Polyphenolic in potato peels was $(3.93 \mathrm{mg} / \mathrm{g}$ ) [Singh and Rajini, 2008].Although potato peels is used for feeding livestock, on other hand it is used as a source for natural antimicrobial compounds [Prasad and Pushpa, 2007]. [Abdel-Magied, 1994] studied using potato peels in other applications such as biscuit product with levels (5\% and 10\% w/w) replaced wheat flour. [Arora A and Camire, 1994 \& Singh and Rajini, 2004] Studied the effect of addition potato peels with level (25\%) on muffins, also using it in food applications. 
[Fadel, 2002] reported that Potato peels contribute in field the products of biotechnology and industrial such as wheat bran, rice bran, molasses bran, barley bran, maize meal, and soybean meal. [Singh and Rajini, 2004] measure the antioxidant activity of potato peels extract is strong activity and this make potato peels as effective element in health or functional food. So this study was carried out to determine total antioxidants and carotenoids in fortified bread with different levels of dried potato peels powder compared to control bread. So the aim of this study was investigate the effect of addition different levels of potato peels with wheat flour to produce some bakery products such as bread rich with antioxidants and carotenoids. On anther hand this paper aimed to raise and improve the antioxidants and carotenoids content of bread by adding different levels of dried potato peels, also the importance of this research was obtained in awareness some people of healthy benefits of vegetable peels especially potato peels.

\section{MATERIAL AND METHODS}

\subsection{Material:}

- Sample of white flour (72\% extraction) was obtained from local market of Cairo - Egypt.

- Sample of dried Potato peels were obtained from fresh Potato tubers Purchased from local market of Cairo - Egypt in November 2015.

\subsubsection{Methods:}

\subsubsection{Sensory evaluation:}

Sensory evaluation of fortified bread with different levels of dried potato peels was included (taste, color, flavour, textures, pores and overall acceptability) compared to control bread according to the method of [Fairdi and Rulenthaler, 1984].

\subsubsection{Preparation of potato peels:}

Fresh potato tubers were washed well by water and remove the peels by using kitchen vegetable peeler. Potato peels was dried by different methods by sun drying or oven drying (hot air oven at $180{ }^{\circ} \mathrm{C}$ for $1 \mathrm{~h}$ ) or solar drying methods according to [Kiremire, et al, 2010]. Then it was grinned in the blender to get soft powder, it was saved in plastic bags and stored in freeze until used. 


\subsubsection{Preparation of wheat flour with potato peels and bread groups:}

Adding different levels of dried potato peels $(5 \%, 10 \%$ and $15 \%)$ to (100 gm) wheat flour (72\% extraction) and mix well with little of water, then adding other contents (salt, yeast, sugar and little of oil) to make bread product, it was leaved for a period of time for fermentation, then it was beaked in oven at temperature $200 \mathrm{oC}$ for 20 minutes. Bread samples was divided into two main groups, the first main group was contained control bread (non fortified) and the second main group was contained fortified bread with different levels of potato peels (5\%,10\% and 15\%), this group was divided into three subgroups are as followed, the first subgroup was consisted of fortified bread with (5\%) dried potato peels, the second subgroup was consisted of fortified bread with (10\%) dried potato peels and the third subgroup was consisted of fortified bread with (15\%) dried potato peels. The samples were evaluated sensory evaluation compared to the control bread. Also these samples were dried in the oven at $200 \mathrm{oC}$ and grinned in blender to get soft powder and preparation for chemical analysis.

\subsubsection{Proximate Chemical Composition:}

Chemical analysis of macronutrients (proteins, fats, carbohydrates, Ash, Moisture and crude Fiber) and micronutrients (Vitamins and minerals):

Determination of nutritional value of raw material (flour and dried potato peels) and food product (fortified white bread with different levels of potato peels $(5 \%, 10 \%$ and $15 \%)$ to study the chemical composition of Proteins, Fats, Carbohydrates, Ash, Moisture, Crude Fiber ,Vitamins and rare compounds such as Total antioxidants and Carotenoids .Proteins, Fats, Carbohydrates, Ash, Moisture, Crude Fiber content was determined according to the method described by [Anderson and Shirley, 2007, Brand Williams et al .1995 and Ranganna, 1979].

\subsubsection{Chemical analysis of micronutrients (Minerals and Vitamins):}

minerals such as ( $\mathrm{Zn}, \mathrm{Cu}, \mathrm{Ca}, \mathrm{Fe}$ and $\mathrm{Se}$ ) in wheat flour and potato peels were determined according to the methods outlined in [A.O.A.C., 2007].The content of vitamin B complex (B1, B2, B3, B6, B9 and B12) were determined according to the methods of [Stephane Castan et al, 2005] 
and vitamin $\mathrm{C}$ contents were determined according to the methods of [Sanchez-Machado et al, 2006].

\subsubsection{Chemical analysis of rare compounds:}

The content of rare compounds (Total antioxidants and Carotenoids) in fortified bread was carried out according to the methods of [Anderson and Shirley, 2007, Brand Williams et al, 1995 and Ranganna, 1979].

\section{Statistical analysis:}

The obtained data were Statistical analyzed using Analysis of Variance (ANOVA). The results were expressed as mean \pm standard diviation"SD" at least significant difference "LSD" tests at a probability $\mathrm{P}<0.05$, according to [Armitaage and Berry, 1987].

\section{Result and discussion:}

Data in Table (1) .Showed mean and least significant different (LSD) at (0.05) of sensory evaluation of control and fortified samples of bread with different levels of dried potato peels (5\%,10\% and 15\%). The results revealed that ,the mean values of sensory evaluation (taste, color, flavour, pores , textures and overall acceptability) were decreased gradually with increasing the level of dried potato peels from (9.7 to 7.8) taste, (9.6 to 7.4) colure, (9.5 to 6.6) flavor, (9.7to 7.2) pores, (9.6 to 7.2) textures. This showed that there are significant differences with increasing level of potato peels. In the end the best results in sensory evaluation were obtained in fortified sample with $(5 \%)$, it were $(9,9,9,8.2$ and 8.2) respectively as compared to control sample $(9.7,9.6,9.5,9.7$ and 9.6).

Table (1): Mean and least significant different (LSD) of sensory evaluation of control and fortified white bread with different levels of dried potato peels.

\begin{tabular}{|l|l|l|l|l|l|l||}
\hline $\begin{array}{l}\text { Mean of Sensory } \\
\text { Evaluation } \\
\text { Samples(Bread) }\end{array}$ & \multicolumn{1}{|c|}{ Taste } & \multicolumn{1}{c|}{ Color } & flavour & Pores & textures & $\begin{array}{c}\text { Overall } \\
\text { acceptability }\end{array}$ \\
\hline \hline Control & $9.7 \pm 0.21$ & $9.6 \pm 0.031$ & $9.5 \pm 0.12$ & $9.7 \pm 0.012$ & $9.6 \pm 0.02$ & 48.1 \\
\hline $5 \%$ & $9 \pm 0.01$ & $9 \pm 0.64$ & $9 \pm 0.41$ & $8.2 \pm 0.74$ & $8.2 \pm 0.75$ & 41.4 \\
\hline $10 \%$ & $8.4 \pm 0.49$ & $8.8 \pm 0.41$ & $7.4 \pm 0.76$ & $7.2 \pm 0.75$ & $7.2 \pm 0.74$ & 41.00 \\
\hline $15 \%$ & $7.8 \pm 0.98$ & $7.4 \pm 0.99$ & $6.6 \pm 1.2$ & $7.2 \pm 0.76$ & $7.2 \pm 0.76$ & 36.2 \\
\hline LSD at 5\% & 0.281 & 0.320 & 0.382 & 0.337 & 0.337 & 1.015 \\
\hline
\end{tabular}


Data in Table (2). Illustrated Chemical composition of Macronutrients of control and fortified bread with different levels of dried potato peels $(5 \%, 10 \%$ and $15 \%)$, the rates of protein, crude fiber, and Ash were significant increased with increasing the level of potato peels compared to control bread $(8.130,10.403,10.450,11.845),(0.351,1.39$, $1.85,2.61),(0.515,1.265,1.322,1.996)$ respectively, This could be due to substitution effect caused by the high levels of protein, fiber and ash in potato peels $(17.572,3.472,4.998)$ respectively according to [Nara et al., 2006] studied that physical and chemical properties of potato peels and he reported that potato peels is containing a high rate of dietary fiber more than wheat bran. but the rats of carbohydrates, fats and moisture were significant decreased with increasing the level of dried potato peels $(98.15,82.307$, $79.706,72.006),(3.781,3.232,3.083,1.109)$, (11.987, $1.722,0.501$, 0.001 ) respectively and the best results were showed in the fortified bread with $(5 \%)$ of potato peels as compared to the control. These results agree with the results [Sharoba et al., 2009] who analyzed wheat flour extraction (72\%) from where (protein, carbohydrate, fat, crude fiber, moisture and Ash) and micronutrient (minerals), [United States Department of Agriculture, National Nutrient Database. International Year of the Potato, 2008] mentioned that Potato is considered of foods rich in carbohydrate, it contains about $80 \%$ water and $20 \%$ dried matter, the protein that found in potato is similar to that found in cereals. In addition, the potato is low in fat, [Mabrouk and El Ahwany, 2008] reported that Potato peels (PP) was as a source of dietary fiber. Which $(50 \%)$ of potato peels $(\mathrm{w} / \mathrm{w})$ is considered dietary fibers.

Table (2): Chemical composition of Macronutrients of control and fortified bread with different levels of dried potatoes peels $(5 \%, 10 \%$ and $15 \%)$.

\begin{tabular}{|c|c|c|c|c|c|c|}
\hline \multirow[t]{2}{*}{ Samples } & \multicolumn{2}{|l|}{ Raw materials } & \multirow{2}{*}{$\begin{array}{l}\text { Control } \\
\text { Bread }\end{array}$} & \multicolumn{3}{|c|}{$\begin{array}{l}\text { Fortified bread with dried } \\
\text { potato peel }\end{array}$} \\
\hline & $\begin{array}{l}\text { White flour } \\
\text { extraction }(72 \%)\end{array}$ & $\begin{array}{l}\text { Dried potato } \\
\text { peels }\end{array}$ & & $5 \%$ & $10 \%$ & $15 \%$ \\
\hline Protein & 11.845 & 17.572 & 8.130 & 10.403 & 10.450 & 11.845 \\
\hline Carbohydrate & 74.193 & 69.973 & 98.15 & 82.307 & 79.706 & 72.006 \\
\hline fat & 1.109 & 0.988 & 3.781 & 3.232 & 3.083 & 1.109 \\
\hline Moisture & 11.987 & 4.776 & 11.987 & 1.722 & 0.501 & 0.001 \\
\hline Fiber & 0.351 & 3.472 & 0.351 & 1.39 & 1.85 & 2.61 \\
\hline Ash & 0.515 & 4.998 & 0.515 & 1.265 & 1.322 & 1.996 \\
\hline
\end{tabular}


Table (3). Demonstrated Chemical composition of vitamins of control and fortified bread with different levels of dried potato peels (5\%, $10 \%$ and 15\%). This data revealed that, the mean values of vitamin B complex and vitamin $\mathrm{C}$ increased gradually with increasing the level of potato peels as compared to the control, There was significantly increase in the vitamin B complex content with increased level of supplementation from (12.01 to 250.96) B1,(0.76 to 16.87) B2, (42.29 to 465.72) B5, (19.60 to 154.96$) \mathrm{B} 6$, (6.02 to 67.53$) \mathrm{B} 9,(1.38$ to 364.83$) \mathrm{B} 12$, because of increasing the content of vitamins in dried potato peels, also There was significantly increase in the content of vitamin $\mathrm{C}$ with increased level of supplementation from (8.45 to 386.59) and the best results were obtained in fortified bread with $(15 \%)$ of dried potato peels. These results agree with [Gropper et al., 2009] whose said that One medium potato with the peels contains $45 \%$ of the daily value for vitamin C, potassium $(620 \mathrm{mg}), 10 \%$ of the daily value of B6, vitamin thiamin, riboflavin, folate, magnesium, phosphorous, iron, and zinc, and [Stushnoff et al., 2007] pointed to that more than $50 \%$ of the nutrients found in the peel more than potato itself. So Vitamins are very important in food because it help to regulate body processes specialty vitamin B complex are particularly essential in carbohydrate, fat and protein metabolism. Thiamine plays a central role in the generation of energy from carbohydrates, riboflavin is involved in the energy production for the electron transport chain and the catabolism of fatty acids. Niacin plays an important role in energy transfer reactions in the metabolism of glucose, fat and alcohol [Gropper et al, 2009].

Table (3): vitamins composition of control and fortified bread with different levels of dried potato peels $(5 \%, 10 \%$ and $15 \%)$.

\begin{tabular}{|c|c|c|c|c|c|c|}
\hline \multirow[t]{2}{*}{ Samples } & \multicolumn{2}{|c|}{ Raw materials } & \multirow{2}{*}{$\begin{array}{c}\text { Control } \\
\text { Bread }\end{array}$} & \multicolumn{3}{|c|}{$\begin{array}{c}\text { Fortified bread with dried } \\
\text { potato peel }\end{array}$} \\
\hline & $\begin{array}{c}\text { White flour } \\
\text { extraction }(72 \%) \\
\end{array}$ & $\begin{array}{c}\text { Dried potato } \\
\text { peels }\end{array}$ & & $5 \%$ & $10 \%$ & $15 \%$ \\
\hline Vit.B1 & 0.00 & 40.521 & 12.01 & 68.22 & 80.30 & 250.96 \\
\hline Vit.B2 & 1.94 & 20.870 & 0.76 & 7.24 & 9.89 & 16.87 \\
\hline Vit.B5 & 41.03 & 581.821 & 42.29 & 205.08 & 232.88 & 465.72 \\
\hline Vit.B6 & 5.08 & 204.391 & 19.60 & 35.12 & 48.17 & 154.96 \\
\hline Vit.B9 & 8.31 & 64.413 & 6.02 & 29.50 & 47.81 & 67.53 \\
\hline \begin{tabular}{|l|} 
Vit.B12 \\
\end{tabular} & 1.34 & 461.112 & 1.38 & 73.21 & 89.96 & 364.83 \\
\hline \begin{tabular}{|l} 
Vit.C \\
\end{tabular} & 21.71 & 443.041 & 8.45 & 9.59 & 23.19 & 386.59 \\
\hline
\end{tabular}


Data in Table (4): Illustrated the comparison between content of minerals ( $\mathrm{Zn}, \mathrm{Cu}, \mathrm{Ca}, \mathrm{Fe}$ and $\mathrm{Se}$ ) in White flour (72\% extraction) and dried potato peels. It was resulted significant increasing of minerals $(\mathrm{Zn}, \mathrm{Cu}, \mathrm{Ca}$, $\mathrm{Fe}$ and Se) in potato peels $(0.515,0.797,39.213,17.998$ and 0.565$)$ respectively compared to wheat flour; it was $(0.457,0.312,12.942,0.726$ and 0.015$)$ respectively. This could be due to the fact that potato peels are rich source of minerals as reported by [Sello, 2011] in evaluating the content of minerals and phenolic in potato and apple peels. The results showed that potato peels has high levels of copper, calcium, copper and phenolic. So minerals are playing an important and vital role in the functional processes of the body including the nervous system, the structural system also the process of water balance.

Table (4): minerals composition of wheat flour and dried potato peels.

\begin{tabular}{|c|c|c||}
\hline \hline Raw materials & $\begin{array}{l}\text { White flour } \\
\text { (72\% extraction) }\end{array}$ & Dried potato peels \\
\hline \hline $\mathrm{Zn}$ & 0.457 & 0.515 \\
\hline $\mathrm{Cu}$ & 0.312 & 0.797 \\
\hline $\mathrm{Ca}$ & 12.942 & 39.213 \\
\hline $\mathrm{Fe}$ & 0.726 & 17.998 \\
\hline $\mathrm{Se}$ & 0.015 & 0.565 \\
\hline
\end{tabular}

Data in Table (5): explained chemical composition of antioxidants and Carotenoids "of control and fortified bread with different levels (5\%, $10 \%$ and 15\%) of dried potato peels. There is significant increasing in the rate of antioxidants with increasing the level of dried potato peels from (17.22 to 55.86) as compared to the control (0.00). Also increasing the rate of carotenoids from (74.9 to 151.587) as compared to the control (27.4) This could be due to substitution effect caused by the high levels of antioxidants and carotenoids in potato peels (87.07 and 59.6)respectively. In the end, the best results were obtained in the high level of potato peels (15\%) because of increasing the content of antioxidants and carotenoids in dried potato peels, also samples were acceptable sensory. These results in line [Mohdaly et al., 2010 \& Al-Weshahy and Rao., 2012] whose compared between sesame cake, sugar beet pulp and potato peels, the results showed that potato peels was superior in the content of Polyphenolic, antioxidant and Their role in human health and [Rasha and Nareman., 2013] compared between potato 
peel and eggplant peels, they reported that potato peels were better than eggplant peels in levels of chlorogenic acid. And the content of total Polyphenolic in potato peels was $(3.93 \mathrm{mg} / \mathrm{g})$ and dry weight based [Singh and Rajini, 2008].So antioxidants are considered very important nutrients for human health according to [Singh and Rajini, 2004] reported that antioxidants in potato peels is considered strong activity and this make potato peels as effective element in health or functional food.

Table (5): Total antioxidants and carotenoids of control and fortified bread.

\begin{tabular}{||c|c|c|c|c|c|c||}
\hline \multirow{2}{*}{$\begin{array}{c}\text { Ramples } \\
\text { Rare }\end{array}$} & \multicolumn{2}{|c|}{ Raw materials } & \multicolumn{2}{c|}{$\begin{array}{c}\text { Control group } \\
\text { (bread) }\end{array}$} & \multicolumn{2}{|c|}{$\begin{array}{c}\text { fortified bread with dried } \\
\text { potato peels groups }\end{array}$} \\
\cline { 2 - 8 } & $\begin{array}{c}\text { White flour } \\
\text { extraction }(72 \%)\end{array}$ & $\begin{array}{c}\text { Dried potato } \\
\text { peels }\end{array}$ & $\begin{array}{c}\text { Sample of } \\
\text { pread }\end{array}$ & $5 \%$ & $10 \%$ & $15 \%$ \\
\hline $\begin{array}{c}\text { Total } \\
\text { antioxidants }\end{array}$ & 21.45 & 87.07 & 0.00 & 17.22 & 35.13 & 55.86 \\
\hline Carotenoids & 2.2 & 59.6 & 27.4 & 74.9 & 121.23 & 151.58 \\
\hline
\end{tabular}

\section{Recommendations:}

According to the obtained results, it could be recommended that:

1- Educate individuals about the available nutrients in vegetables peels such as antioxidants and carotenoids also its health benefits for human body.

2-Patients whose are suffering from Deficiency of vitamins and minerals could be recommended eating vegetables with peels.

3-people suffering from anemia, blood pressure, high cholesterol, heart disease and Arteriosclerosis should be eating potato with peels.

4- Could be making Potato with peels some applications such as fried potato or Stuffed Potato with peels.

5-Vitamins, minerals and rare compounds were very useful for human health so, should be eating vegetables with peels because of it is high in these contents.

6- Can be increasing the nutrient value of some foods by supplemented with vegetable peels or eating vegetables with peels.

7-Should be using vegetables peels in some bakery products such as (bread, Patton salee, pizza and pies). 


\section{Conclusion:}

vegetable peels are rich in important and useful nutrient for human health such as antioxidant and carotenoids, so the aim of this work was to determinate of the total antioxidants and carotenoids in fortified bread with dried potato peels. The results of sensory evaluation were obtained that, fortified bread was acceptable until level (15\%) dried potato peels as compared to control bread, and the best results showed in low level of dried potato peels (5\%) more than the two levels (10\% and 15\%). Fortified bread was recorded gradually increasing in vitamin B complex, vitamin C, minerals and rare compounds (Total antioxidants and Carotenoids) with increasing the level of dried potato peels. So it should be eating potatoes tubers with peel or after washing well because of it is contain useful nutrients for human health such as antioxidants and carotenoids, also vitamins and minerals.

\section{REFERENCE:}

- Abdel-Magied MM. (1994). Effect of dietary fiber of potato peel on the rheological and organoleptic characteristics of biscuits. Egyptian Journal of Food Science. 19:293-300.

- Al-Weshahy and V.A. Rao. (2012). Potato Peel as a Source of Important Phytochemical Antioxidant Nutraceutical and Their Role in Human Health - A Review, Phytochemicals as Nutraceutical - Global Approaches to Their Role in Nutrition and Health, Dr Venketeshwer Rao (Ed.).

- Anderson and Shirley. (2007). Journal of AOAC International, Volume 90, Number 4, pp. 1073-1083(11).

- Armitaage and Berry. (1987). Statistical methods in medical research. Blackwell, Oxford., PP. 93-212.

- Arora A and Camire ME. (1994). Performance of potato peels in muffins and cookies. Food Research International, 27:15-22.

- Ballesteros MN, Cabrera RM, Saucedo MS, Yepiz-Plascencia GM, Ortega MI and Valencia ME.(2001) Dietary fiber and lifestyle influence serum lipids in free living adult men. Journal of the American College of Nutrition, 20(6):649-655.

- Bowles, S., and Demiate, I. M. (2006). Physicochemical characterization of the soymilk by product - okara. Ciência e Tecnologia de Alimentos., 26(3), 652659. 
- Brand-Williams W, Cuvelier ME and Berset C.(1995). Use of free radical method to evaluate antioxidant activity, Food Science and Technology, 28, 2530 .

- Brown, C. (2005). Antioxidants in potato. American Journal of Potato Research., 82:163-172.

- Cook NR, Obarzanek E, Cutler JA, Buring JE, Rexrode KM, Kumanyika SK, Appel LJ and Whelton PK.(2009). Joint effects of sodium and potassium intake on subsequent cardiovascular disease. Arch Intern Med., 169:32-40.

- Cotton PA, Subar AF, Friday JE and Cook A.(2004). Dietary sources of nutrients among US adults, 1994-1996. J Am Diet Assoc., 104:921-930.

- Crésio Alves and Renata Villas Boas Lima, (2009). Dietary supplement use by adolescents. Jornal de Pediatria - Vol. 85, No. 4, 2009.

- Dawson-Hughes B. (2008). Alkaline diets favor lean tissue mass in older adults. Am J Clin Nutr., 87:662-665.

- Fadel M. (2002), Utilization of potato chips industry by products for production of thermostable bacterial alpha-amylase using solid state fermentation system. 2 . Effect of moistening agent, supplementary substrates nitrogen source, and application of the solid fermented substrate for some starches digestion. Egyptian Journal of Microbiology. 34(4):533-546.

- FAO Food and Nutrition Paper 66. (1997). Carbohydrates in Human Nutrition. Report of an FAO/WHO Expert Consultation on Carbohydrates, Rome, Italy. FAO, Rome, 1998.

- Faostat, Volume, (2009); 2009.

- Faridi, H.A and Rubenthaler G.L. (1984). Effect of baking time and temperature on bread quality, starch gelatinization and staling of Egyptian balady bread. Cereal chem., 61 (2): 151-154.

- FDA. (2002). Food and Nutrition board, Institute of medicine dietary reference intake for water, potassium, sodium, chloride and sulfate, Washington, DC: national academy press, 2002.

- FDA. (2004). Food and Nutrition board, Institute of medicine dietary reference intake for energy, carbohydrate, fiber, fat, fatty acids, protein and amino acids, Washington, DC: national academy press, 2004.

- Fischer, K. and Bipp, H.P. (2005). Generation of organic acids and monosaccharides by hydrolytic and oxidative transformation of food processing residues. Bioresource Technology., 96 (7): 831-842. 
- Food and Drug Administration (2014). "Consumers - Dietary Supplements: What You Need to Know". Fda.gov. Retrieved 26 June 2014.

- Friedman M., Chemistry.(1997). Biochemistry and dietary role of potato polyphenols. Journal of Agricultural and Food Chemistry, 45(5):1523-1540.

- Gropper SS, Smith JL and Groff JL. (2009). Advanced Nutrition and Human Metabolism. $5^{\text {th }}$ Ed. Thomson, Wadworth., pp. 316, 421-425.

- Guallar E, Stranges S, Mulrow C, Appel LJ and Miller ER. (2013). "Enough is enough: Stop wasting money on vitamin and mineral supplements". Ann. Intern. Med. (Editorial)., 159 (12): 850-1.

- Hamendra, S. P, Yamini, D, and Anand Kar. (2010) Fruit and vegetable peels: Paving the way towards the development of new generation therapeutics, Drug Discoveries \& Therapeutics., 4(5):314-325.

- Hasegawa, D., R.M. Johnson, and W.A. Gould.(1966). Effect of cold storage on chlorogenic acid content of potatoes. Journal of Agricultural Food Chemistry, 14:165-169.

- Kiremire BT. Musinguzi E. Kikafunda Jk. And Lukwago FB.(2010). Effects of vegetable drying techniques on nutrient. African J. Of Food Agric.Nut.And Development., Vol.10. (5):1-14.

- Lachman J, Hamouz K, Orsak M, Pivec V and Dvorak P. (2008). The influence of flesh color and growing locality on Polyphenolic content and antioxidant activity in potatoes, Scientia Horticulturae., 117: 109-114.

- Lin B-H and Yen ST., U.S.(2004). Potato consumption: Looking ahead to 2020. / Food Prod Market, 10(2):49-65.

- Mabrouk EMM and El Ahwany MDA. (2008). Production of $\beta$ - mannanase by Bacillus amylolequifaciens 10A1 cultured on potato peels. African Journal of Biotechnology, 7(8):1123-1128.

- Mohdaly AA, Sarhan MA, Smetanska I and Mahmoud A. (2010). Antioxidant properties of various solvent extracts of potato peel, sugar beet pulp and sesame cake. Journal of the Science of Food and Agriculture, 90(2):218- 226.

- Nara K, Miyoshi T, Honma T and Ioscience.(2006). Biotechnology and Biochemistry, 70(6):1489-1491.

- Nowson CA, Worsley A and Margerison C. (2004). Blood pressure response to dietary modifications in free-living individuals. J Nutr, 134(9):2322-9. 
- Parmar, H.S, and Kar, A. (2009). Comparative analysis of free radical scavenging potential of several fruit peel extracts by in vitro methods. Drug Disc Ther, 3:49-5.

- Prasad AGD and Pushpa HN.(2007). Antimicrobial activity of potato peels waste. Asian Journal of Microbiology, Biotechnology and Environmental Sciences, 9(3):559-561.

- Ranganna, S. (1979). Manual of Analysis of Fruit and Vegetables Products. $2^{\text {nd }}$ Edn, Tata Me Graw-Hill Publ. Co. Ltd., New Delhi, India, Pages: 634.

- Rasha M.A. Mousa and Nareman S. Eshak. (2013). Safe and economic antioxidant blends from potato and eggplant peels with good overall sensory acceptability. International Conference of "Applied Human Science \& the Technology in the Third Millennium".

- Sanchez-Machado D.I, Lopez-Cervantes and N.J. Rios Vazquez.(2006). Highperformance liquid chromatography method to measure $\alpha$-and $\gamma$-tocopherol in leaves, flowers and fresh beans from Moringa oleifera, Journal of Chromatography A, 1105, 111-114.

- Sello, A.A.A.EL. (2011).The hepatoprotective effect of potato and apple peels as antioxidant on intoxicated rats with ccl4, Research Journal Specific Education Faculty of Specific Education Mansoura University, Issue No. 22, Jul.

- Sharoba, A. M. A.; A. I. El-Desouky; M. H. M. Mahmoud and Youssef, Kh. M.(2009). Quality attributes of some breads made from white flour substituted by different levels of whole amaranth meal. J. Agric. Sci. Mansoura Univ., 34 (6): $6601-6617$.

- Singh N and Rajini PS.(2004). Free radical scavenging activity of an aqueous extract of potato peel. Food Chemistry, 85(4):611-616.

- Singh N and Rajini PS. (2008). Antioxidant-mediated protective effect of potato peels extract in erythrocytes against oxidative damage. Chemical-Biological Interactions, 173(2):97-104.

- Stephane Castan, Claude Villard, Stefan Jakob, Antoine Puigserver and El Hassan Ajandouz, A. (2005). Fast, sensitive method for the simultaneous determination of alfa-tocopherol and alphatocopheryl acetate in mixed micelles, Journal of Chromatography B., 822:339-346.

- Stushnoff CD, Holm H and Thompson NI. (2007). Antioxidant properties of potato cultivars. $91^{\text {st }}$ Annual Meeting of the Potato Association of America. Idaho Falls, ID. Aug. 12-16. 
- Crésio Alves and Renata Villas Boas Lima, (2009). Dietary supplement use by adolescents. Jornal de Pediatria - Vol. 85, No. 4, 2009.

- United States Department of Agriculture, National Nutrient Database. International Year of the Potato, (2008).

- Venketeshwer, R. (2012). Phytochemicals as nutraceutical -Global approaches to their role in nutrition and health. Published online 23, March., 2012, Pages 278 . 


\section{التقدير الكلى الغادات الأكسدة والكاروتينات فى الخبز الأبيض المدعم \\ بمستويات هختلفة هن قشر البطاطس المفف}

*ثاء محمود هاشمجرودة

\section{الملاخص العربي}

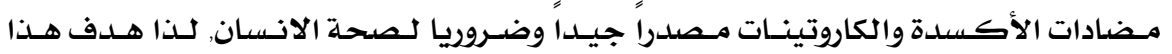

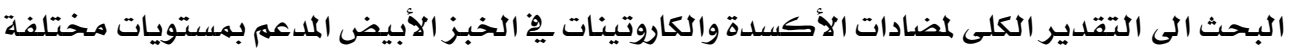

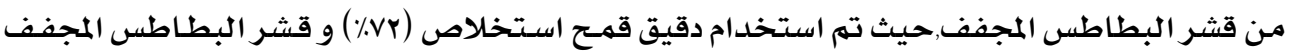

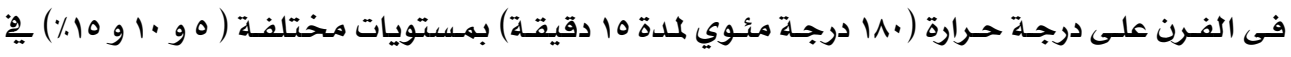

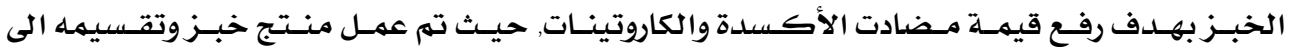

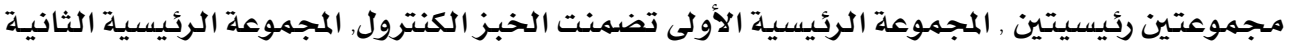

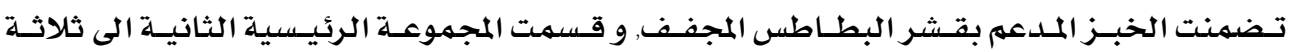

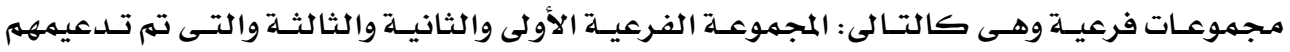

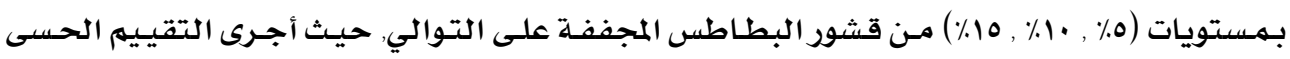

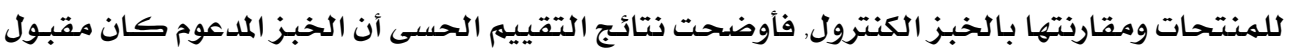

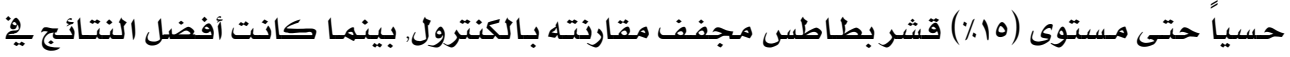

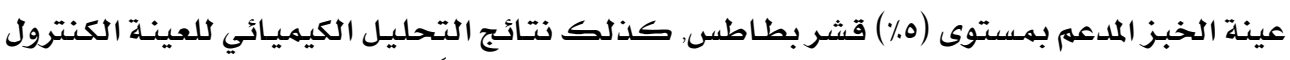

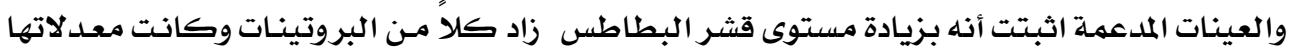

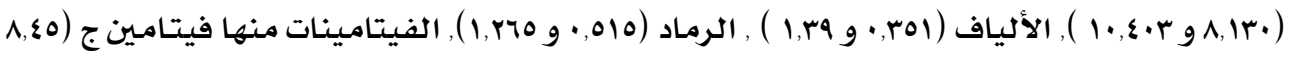

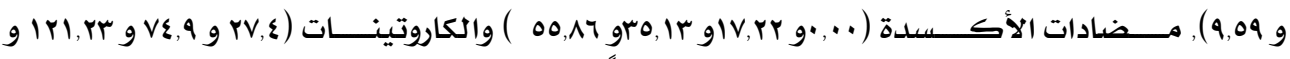

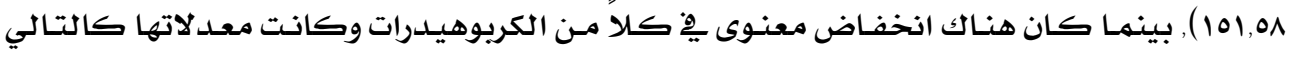

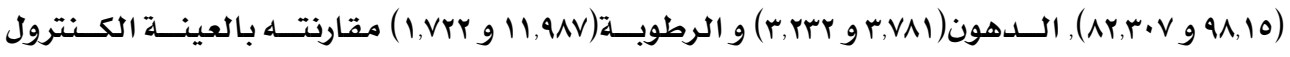
•) (الضابطة)

الخلاصة:

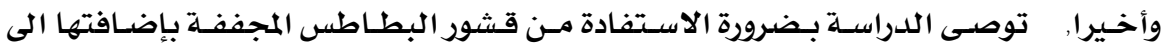

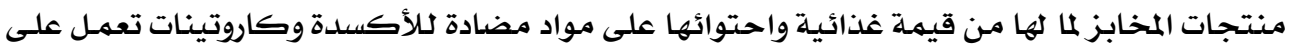

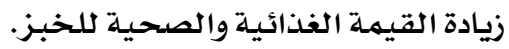

